\title{
Motivation of 14 Year-old Students using Tablets, compared to those using Textbooks and Workbooks
}

\author{
https://doi.org/10.3991/ijim.v12i4.9203 \\ David Mendez $\left.{ }^{(}\right)$, Miriam Mendez, Juana Anguita \\ University Alfonso X el Sabio, Villanueva de la Cañada, Spain \\ dmendcoc@uax.es
}

\begin{abstract}
Intrinsic motivation is important and it can be divided in different dimensions. The Self-Determination Theory is based on intrinsic motivation. The test based on this theory was given to 14-year old students from three different schools: one where students used tablets in the science class during the 2015-16 school year, and two schools where students used textbooks and workbooks for the same subject in the classroom and at home. The test measured three dimensions of intrinsic motivation: interest and satisfaction in connection with the tasks they perform, how they perceive their competence to use the necessary tools to study and the value of the tasks they perform. The results show that students using tablets are more motivated in the three dimensions measured by the test than those using the textbook.
\end{abstract}

Keywords-self-determination theory, motivation, science, tablet, textbook

\section{Self-determination theory}

As defined by Deci \& Ryan [1] in their study of motivation, to be motivated means to be moved to do something or to persist in a conduct, in a specific context. Manassero \& Vázquez [2,3] presented a historical overview of the evolution of the concept of motivation, focusing on the motivation of achievements, on the instruments to measure said motivation and on the assessment of the dimensions it comprises. During the first half of the twentieth century the theoretical description of motivation was dominated by the mechanistic paradigm, which considered instinct, impulse, activation, etc., as the main variables. These theories were led by Hull [4] and Tolman [5]. However, this conception started to wane in the face of the idea of reward and its implication in motivation. A variety of rewards surround a series of different motivations in support of the cognitive paradigm that emerged in the second half of the century, which finally triumphed over the mechanistic approach. This new approach focuses on the motivation of achievement, which is defined as the motivation resulting from the desire to achieve a goal. We owe the theoretical formalization of the motivation of achievement to Atkinson [6], although the contributions to the theory made by Heider [7], Jones \& Davis [8], Kelley [9] and Weiner [10] should also be noted. This formalization was the basis for the expectancy-value theories that consid- 
er motivation as the product of expectations and of the value given to the result one hopes to achieve.

For some time now learning has been considered as a process that entails cognitive and motivational aspects [11]. The impact of motivation on academic performance is well documented [12]. Grant \& Dweck [13] argued that motivation of achievement could be better understood in terms of achievement goals. As a conclusion of their experiments, these authors highlight that learning goals influence positively on intrinsic motivation and on performance when individuals face prolonged challenges, being learning goals defined as the efforts made to learn something new, insisting on the importance and the benefits of acquiring new knowledge. McInerney, Marsh \& Yeung [14] suggested that establishing goals was the catalyzer for directing a person's energy towards achieving desired results. Pintrich \& De Groot [15] stated that there were three major components for the study of school motivation: one's perceived competence to become involved in the task, the value or beliefs regarding the importance or benefits attributed to performing the task, and the affective-emotional reactions produced.

Schunk [16] defined a goal as a standard or norm of demand whereby persons judge their success or failure. According to Grant \& Dweck [13] there were two classes of goals: performance objectives and learning objectives (command or mastery). Performance goals were related to validating one's capability, whereas learning goals focused on making an effort to learn and have command. The performance goal approach focuses above all on the "me", whereas the learning objectives or mastery approach focuses on the learning activity $[17,18]$.

Learning or mastery goals were positively associated with intrinsic motivation and academic performance. It was also found that command objectives are associated with self-efficacy, positive emotions and general well-being [19].

Some authors suggested that performance objectives could be divided into objectives of approach (achieve success) and objectives of avoidance (avoid failure). Although the association of goals and results of the performance approach continued to be the center of discussion, the performance-avoidance goals were negatively related with performance [19].

As pointed out by Manassero \& Vázquez [2, 3], at present when we speak of motivation there is not a single theory shared by everyone. Instead, several approaches arising from aspects connected to the aforementioned theory, in other words with achievement objectives, coexist:

- The expectation of achieving goals that Atkinson [6] related with competence and the information that we obtain from others.

- Motivation as a personal investment is determined by what you feel about yourself (in other words, how you do something, if you do for yourself and what leads you to do it), what you expect to gain by doing it (incentives), the intrinsic motivations (such as power), what you could contribute to society, extrinsic motivations (such as acknowledgement or rewards) and finally the alternatives [20].

- Self-efficacy (in other words, what we think we are able to do when we want to do something), which is what influences motivation in the framework of Bandura's 
[21] theory of social-cognitive learning. Learning is conditioned by how we do it and the expectations we have regarding what we achieve.

- How environment and personality complement and relate one another, so that they condition behavioral goals. In this respect Dweck \& Legget [22] speak of the causal attribution theories (the consequences of which can be desirable or undesirable).

Intrinsic motivation has appeared as an important phenomenon for educators, a natural source of learning and achievements that can be systematically catalyzed or undermined by the practices of parents and teachers [23].

Ryan \& Deci [24] define intrinsic motivation as the realization of an activity due to its inherent satisfactions more than because of some separable consequence. When intrinsically motivated, a person is moved to act for the fun or challenge involved and not as a result of external pressures or rewards.

Depending on the fulfillment of the three basic psychological needs, students' intrinsic motivation could increase, leading them to adopt an active position in the learning process. The quality of motivation, whether intrinsic or extrinsic, selfregulated or controlled externally, is of major importance for the learning process [25].

In the field of education the different theories of motivation have been considered of importance, including the self-determination theory, amongst others, which is backed by significant empirical evidence focused on intrinsic motivation [26].

Deci \& Ryan [1] defend that a person has three basic innate needs: need of competence, or achievement; need for autonomy, or the inner sensation of control and freedom of choice; and the need to feel related to others, or the need to belong to a group. When these needs are met, motivation and well-being increase, facilitating the natural trend of human beings to grow. Intrinsic motivation does not stem from need, but rather from the process of self-determination. In other words, when the individual acts voluntarily and chooses what, how and when to do something, this is based on the idea of a person with an innate tendency for development, learning and selfmotivation [27].

Intrinsic motivation confirms the positive potential of human nature towards action. This type of motivation facilitates the exercise of one's own capacities in the absence of rewards. Maintaining this tendency requires support.

The results of different empirical studies[28] confirm that intrinsic motivation decreases when the individual considers that his/her actions are determined extrinsically, and performs them as a means to achieve an objective established by someone else, rejecting this innate trend towards responsibility and growth of human beings. The same happens when the individual perceives threats, dates of inflexible compliance, pressure of tests or very controlling educators.

Another finding of this theory is that rewards for tasks performed cause the individual to feel capable. This can facilitate intrinsic motivation, like challenges and the perception of autonomy when it comes to choosing activities. Educators who allow students to choose and self-guide themselves are facilitators of intrinsic motivation, and in consequence, of initiative, of the aptitude for questioning, of creativity, etc. However, we cannot forget the third innate human need, namely relations, which also 
have an influence on motivation and wellbeing; the contexts in which security, confidence and affection reign allow intrinsic motivation to surface [1].

All these findings were made using the Intrinsic Motivation Inventory (IMI) [29], a multidimensional test that tries to assess participants' subjective experience in performing certain tasks. It has been used in multiple experiments in connection with self-regulation and intrinsic motivation [28].

\section{Effects of technology on motivation}

ICTs have become the motor of growth of the world economy, and their presence has increased in all dimensions of society and people's lives [30]. The OECD [31] encourages the development of ICT competences at the different school levels in order to prepare young people for adult life.

Educational policies have reflected this growing need and the benefits that stem from the use of technologies in education. For years we have been witnessing the integration of technology in educational centers as a teaching resource and/or as a methodology that can favor comprehension and assimilation of contents and/or increase students' motivation and/or develop different competences and life-skills that students need for life [32].

It has been proven that the use of ITCs increases students' motivation for learning, because it gives them more control over their own educational experience [33, 34].

For this reason, it is necessary to increase the infrastructure in schools and to develop the knowledge and competences in the use of technological resources amongst teachers. In doing so, teachers can use them effectively and with quality in the subject they teach and in management of their classrooms [32].

The advantages of technological resources applied to education are summarized below [35]:

1. They have an influence on student's daily life and are present in informal education.

2. They stimulate communication and offer multiple possibilities of application.

3. They facilitate the development of students' research capacity.

However, the use of ICTs in classroom work does not seem to correspond to the achievements they are attributed [36]. The reasons given for this deferment include the scarcity of technological teacher training [37]. In a study with teachers, Preston, Cox \& Cox [38] concluded that the factors that motivated teachers most in their use of ICTs were: the capacity they perceive they have to use them, the difficulties they come across in their use, the level of the available resources and their satisfaction with them, and whether the use of the technology is considered interesting and entertaining. Teachers and students are increasingly in agreement regarding the utility of ICTs for learning, the acquisition of competences, the development of skills and the comprehension of educational contents [39]. The use of ICTs in classroom activities results in classes that are more active and more participative, producing greater motiva- 
tion $[40,41]$. However, some authors also indicate that students prefer not using tablets in class because they distract them [42].

At present the use of mobile technology in classrooms has increased with the growing use of laptops, cell phones and tablets. M-learning is the name given to the type of learning that occurs by means of mobile technological devices, characterized by its ubiquity. However, the definition of mobile learning has passed through different perspectives, ranging from points of view focused on the technology used for learning to the theories conceiving mobile learning as a learning centered on the students, contexts and mobility. For Sharples, Taylor \& Vavoula [43, 44], in the era of mobile technology, the process of education is conceived as a conversation in a context that is made capable by the constant interaction through and with personified and mobile technology. Learning is mediated by knowledge and technology as instruments for productive research, in a situation of mutual support and a relationship that is changing dynamically. These devices offer advantages, such as facilitating cooperative learning experiences, diminishing the formality of learning and helping to increase self-confidence [45-47].

\section{Methodology}

The objective is to know and compare the motivation provoked in 14 year old students by the use of tablets, and the use of textbooks and workbooks as work tools in the science class, through the measuring of three dimensions of motivation: interest and satisfaction with which they perform tasks, the manner in which they perceive their competence when they use these tools, and the value they assign to the tasks performed.

Intrinsic motivation was measured by a test based on the Intrinsic Motivation Inventory (IMI), which consisted of 17 questions with answers graded on a Likert scale. The sample consisted of 13 and 14-year old students in 2nd year of Compulsory Secondary Education [ESO by the Spanish acronym] and the test was given in three schools: one used tablets to perform the science tasks with a series of applications and internet in class and at home, while the other two used the textbook and workbook to perform the science tasks. The three schools were in the same area and the families had a similar social and cultural level.

At the school where tablets were used, a total of 58 students were divided into two groups. Schools where the textbook and the workbook were used were divided as such: the fist school had a group of 25 students; the second school had two groups, one with 30 students and the other with 27 . In this study the 58 students who used tablets will be referred to as the TABLET group and the 82 who used textbooks will be referred to as the TEXTBOOK group.

The test was given during a class in the month of January of the 2015-2016 school year, right after the Christmas holidays. The students had been using tablets and textbooks for the entire school year up to that time. The ones who used tablets had been doing so for three years. The test lasted 30 minutes. 


\subsection{Instrument}

The intrinsic motivation test given to the students consisted of 17 questions with Likert scale. The answer students had to select was 1 to 5 for each item, 1 being equivalent to Nothing and 5 to A lot.

This instrument assessed the following dimensions: the subject's satisfaction or interest for a specific activity, his/her perception of the competence he/she has and the value or utility provided by the activity in which the subject is participating. All of these dimensions are closely related with the three innate needs assigned to human begins by the Self-Determination Theory. Six items referred to the student's interest or satisfaction for the task he/she is performing, six to how competent the student considers himself/herself to be in using the textbook or the tablet, and five asking about the utility or the value they assign to the tasks they perform.

\section{$4 \quad$ Results}

The answers to the different items are shown below according to the dimensions measured by the test used. Table 1 shows the results of the items related to the interest and satisfaction shown by students regarding the tasks they perform.

Table 1. Average of students' answers to questions regarding their interest and satisfaction in connection with the tasks they perform

\begin{tabular}{|l|c|c|}
\hline \multicolumn{1}{|c|}{ Item } & Textbook & Tablet \\
\hline I enjoy working at school and at home & $3.13 \pm 1.67$ & $3.83 \pm 1.32$ \\
\hline I have a good time working at school and at home & $3.90 \pm 1.32$ & $3.83 \pm 1.10$ \\
\hline After having worked on school tasks, I feel better & $1.67 \pm 1.10$ & $3.87 \pm 1.26$ \\
\hline I really wanted to use my book/tablet to do my school tasks & $2.40 \pm 1.67$ & $3.63 \pm 1.40$ \\
\hline I enjoyed it when the teacher told u show to work in class & $2.00 \pm 1.18$ & $3.40 \pm 1.50$ \\
\hline
\end{tabular}

Students who work with tablets express greater interest and satisfaction in five of the six questions. Students who use the textbook only obtain a lightly higher result, namely 3.90 compared to 3.83 , for the item that refers to having a good time at school and at home. The most significant difference, namely 2.20 points, is for the question about how they feel when they do their work. The average in these questions for the Tablet group 3.67 and for the Textbook group it's 2.74.

The results shown in Table 2 have to do with the second dimension of the test, namely how students perceive their competence when using the necessary tools to study, whether it be in the case of the textbook or that of the tablet.

The students of the Tablet group consider themselves competent when using the electronic device to do their school work, and their results are better than those of students using the textbook for all six items. Furthermore, students using tablets state that they see their work as something they want to do, whereas the other group expresses indifference in respect to this item. The result is similar only for how good they consider themselves to be in the tasks they perform. The greatest difference is in 
the item "I like the way I was taught to use the book/tablet to do my school work". For these questions, the average of the Tablet group is 3.71 and that of the students working with the textbook is 2.66 .

The results in the dimension regarding the value of the tasks are shown in Table 3.

Table 2. Average of students' answers to questions regarding how they perceive their competence to use the necessary tools to study

\begin{tabular}{|l|c|c|}
\hline \multicolumn{1}{|c|}{ Item } & Textbook & Tablet \\
\hline I think I am good in tasks done in the workbook/tablet at school & $3.40 \pm 1.64$ & $3.67 \pm 1.44$ \\
\hline I am satisfied with the work I do with the help of the book/tablet & $2.54 \pm 1.36$ & $3.57 \pm 1.26$ \\
\hline I think that I use the book/tablet better than my classmates & $2.90 \pm 1.60$ & $3.66 \pm 1.35$ \\
\hline I think that I understand very well how I have to work at school and at home & $2.30 \pm 1.34$ & $3.97 \pm 1.08$ \\
\hline I like the way I was taught to use the book/tablet to do my school work & $2.60 \pm 1.20$ & $4.17 \pm 1.07$ \\
\hline I see my work as something that I want to do and not as an obligation & $2.20 \pm 1.19$ & $3.20 \pm 1.58$ \\
\hline
\end{tabular}

Table 3. Average of students' answers to questions regarding the value of the tasks they perform

\begin{tabular}{|l|c|c|}
\hline \multicolumn{1}{|c|}{ Item } & Textbook & Tablet \\
\hline I think it's important to use the workbook/tablet for school work & $3.47 \pm 1.84$ & $3.87 \pm 0.96$ \\
\hline $\begin{array}{l}\text { I think that learning at school with the workbook/tablet is something good } \\
\text { for me }\end{array}$ & $2.93 \pm 1.61$ & $3.20 \pm 1.35$ \\
\hline I think about working at school and at home & $2.17 \pm 1.27$ & $4.00 \pm 0.89$ \\
\hline $\begin{array}{l}\text { I think that using the workbook/tablet at school has been of great value for } \\
\text { me }\end{array}$ & $2.13 \pm 1.05$ & $3.70 \pm 0.90$ \\
\hline I feel like working more when I use the book/tablet (or the workbook) & $2.93 \pm 1.52$ & $3.17 \pm 1.42$ \\
\hline
\end{tabular}

In this dimension the results are also different, and students working with tablets have higher scores on all items. They consider that working with a tablet has been of great value for them, and that when they use this electronic device they feel like working more. The smallest difference between the two groups is in respect to students' consideration of having learned to use the tools to perform the tasks. The biggest difference is that students who use the tablet think about working at home and at school. In this case, the average of students working with the tablet is 3.59 and the average of those working with textbooks is 2.73 .

The students who work with tablets have better results in 16 of the 17 questions than those using the textbook. To observe if the difference is significant, the theoretical value of $\chi^{2}(0.05)$ is 24.996 , whereas the value that results from the study is 54.387. Hence, the difference is significant.

\section{Discussion}

Sanz [48] speaks of the effects of integration and incorporation of tablets in the classroom. He highlights that students positively value everything a tablet offers $(91 \%$ acceptance), coinciding on this point with the data obtained in our research, which 
show that with tablets students value more the work done. This explains why students in the tablet group have a score of 3.71 on the questions referred to this dimension.

Moreover, students surveyed by Sanz believe that it is easier to work with tablets since the information given is clearer and more uniform (47\% mark the option "significantly" or "completely").

This is confirmed by the study's results, since in the aforementioned sample students with tablets express greater motivation in 16 of the 17 questions, and students using textbooks and workbooks only obtain a slightly higher result of 3.90 compared to 3.83 in one question, namely "I have a good time working at school and at home", although the standard deviation is greater.

An idea that was not directly considered in the test was the use of the tool as support for cooperative work. Sanz pointed out that $74 \%$ of students believed that the tablet had a clear cooperative use, and that it promoted said use.

\section{Conclusions}

According to the data obtained, students who use tablets are more motivated than those using textbooks in the three dimensions measured by the test used.

In respect to each one of these dimensions, students who use tablets achieve better results with less standard deviation in 13 of the 17 questions; in other words, the students who use tables show greater homogeneity in their answers.

As for interest and satisfaction regarding the tasks performed, they have better results in five of the six questions with a smaller deviation. The difference between the answers of one group and the other is 0.97 , nearly one point.

The difference is even greater when students are asked about how they perceive their competence when using the work tools. In this case the students using tablets have higher scores for all questions; the difference in this dimension is 1.05 .

In the third dimension, the tablet group considers the tasks performed and the use of the electronic device to be more useful in comparison with the students who use the textbook. However, the difference, which is 0.86 , is smaller than in the other two dimensions. Once again, the tablet group obtains higher scores for all questions.

Therefore, the use of tablet gets a significant positive impact in the students' motivation that it must be considered for the future in order to substitute the textbook and workbook.

\section{$7 \quad$ Acknowledgment}

The funds are provided by Foundation Universidad Alfonso X el Sabio and Santander Bank. 


\section{References}

[1] Deci, E. L. \& Ryan, R. M. (2000). Self-Determination Theory and the Facilitation of Intrinsic Motivation, Social Development, and Well-Being. American Psychologist, 55: 1, 68-78 https://doi.org/10.1037/0003-066X.55.1.68

[2] Manassero, A. M. \& Vázquez, A. (1998). Validación de una escala de motivación de logro. Psicothema, 10(2): 333-351.

[3] Manassero, A. M. \& Vázquez, A. (2000). Análisis empírico de dos escalas de motivación escolar. Revista electrónica de motivación y emoción, 3:5-6.

[4] Hull, C. L. (1925). An automatic correlation calculating machine. Journal of the American Statistical Association, 20, 522-531. https://doi.org/10.1080/01621459.1925.10502926

[5] Tolman, E.C. (1932). Purposive behavior in animals and men. New York: Appleton.

[6] Atkinson, J. W. (1964). An introduction to motivation. Princeton, N.J. Van Nostrand.

[7] Kelley, H. H. (1967). Attribution theory in social psychology. In D. Levine (Ed.), Nebraska Symposium on Motivation, (volume 15, 192-238). Lincoln: University of Nebraska Press.

[8] Jones, E. E. y Davis, K. E. (1965) From acts to dispositions: the attribution process in social psychology, in L. Berkowitz (ed.), Advances in experimental social psychology (Volume 2, pp. 219-266), New York: Academic Press.

[9] Heider, F. (1958). The psycology of Interpersonal Relations. New York: Wiley https://doi.org/10.1037/10628-000

[10] Weiner, B. (1985). An Attributional Theory of Achievement Motivations and Emotion. Psychological Review, 92(4), 548-573. https://doi.org/10.1037/0033-295X.92.4.548

[11] Valle, A., González, R., Barca, A. \& Núñez, J.C. (1996). Una perspectiva cognitivomotivacional sobre el aprendizaje escolar. Revista de Educación, 311, 159-182.

[12] Bello, I., Steffen, J. \& Hayashi, K (2011). Cognitive motivational systems and life satisfaction in serious and persistent mental illness. (Report). Quality of Life Research. 20 (7): 1061(9).

[13] Grant, H. \& Dweck, C. S. (2003). Clarifying achievement goals and their impact. Journal of personality and social psychology, 85(3), 541. https://doi.org/10.1037/00223514.85.3.541

[14] McInerney, D. M., Marsh, H. W. \& Yeung, A. S. (2003). Toward a hierarchical goal theory model of school motivation. Journal of Applied Measurement, 4, 335-357.

[15] Pintrich, P. R. \& De Groot, A. (1990). Motivational and self-regulated learning components of classroom academic performance. Journal of Educational Psychology, 82, 33-40. https://doi.org/10.1037/0022-0663.82.1.33

[16] Schunk, D. H. (2003). Self-efficacy for reading and writing: Influence of modelling, goal setting, and self-evaluation. Reading and Writing Quarterly, 19, 159-172. https://doi.org/10.1080/10573560308219

[17] Maehr, M. L. (2001). Goal theory is not dead - Not yet anyway: A reflection on the special issue. Educational Psychology Review, 13, 177-185. https://doi.org/10.1023/A:100 $\underline{9065404123}$

[18] Maehr, M. L. \& Meyer, H. A. (1997). Understanding Motivation and Schooling: Where We've Been, Where We Are and Where We Need to Go. Educational Psychology Review, 9(4), 371-409.

[19] Kaplan, A. \& Maehr, M. L. (2007). The contributions and prospects of goal orientation theory. Educational Psychology Review, 19, 141-184. https://doi.org/10.1023/A:1024 $\underline{750807365}$ 
[20] Maehr, M. L. \& Braskamp, L. A. (1986). The motivation factor: A theory of personal investment. Lexington, MA, England: Lexington Books/D. C. Heath and Com.

[21] Bandura, A. (1986). From thought to action: Mechanisms of personal agency. New Zealand Journal of Psychology, 15, 1-17.

[22] Dweck, C. S. \& Leggett, E. L. (1988). A social-cognitive approach to motivation and personality. Psychological Review, 95(2), 256-273. doi:10.1037/0033-295X.95.2.256. https://doi.org/10.1037/0033-295X.95.2.256

[23] Ryan, R. M. \& Stiller, J. (1991). The social contexts of internalization: Parent and teacher influences on autonomy, motivation and learning. In P R. Pintrich \& M. L. Maehr (eds.), Advances in motivation and achievement (Vol. 7, pp. 115-149). Greenwich, CT: JAI Press.

[24] Ryan, R. M., \& Deci, E. L. (2000). Intrinsic and extrinsic motivations: Classic definitions and new directions. Contemporary educational psychology, 25(1), 54-67. https://doi.org/10.1006/ceps.1999.1020

[25] Gottfried, A. E. (1985). Academic intrinsic motivation in elementary and junior high school students. Journal of Educational Psychology, 77(6), 631-645. https://doi.org/10.1037/0022-0663.77.6.631

[26] Pintrich, P. R. \& Schunk, D. H. (2006). Motivación en contextos educativos. Teoría, investigación y aplicaciones. Madrid: Pearson

[27] Deci, E. L., Vallerand, R. J., Pelletier, L. G. \& Ryan, R. M. (2011). Motivation and Education: The Self-Determination Perspective. Educational Psychologist, 26, 3-4, 325-346.

[28] Deci, E. L. \& Ryan, R. M. (1991). A motivational approach to self: Integration in personality. In R. Dienstbier (Ed.), Nebraska Symposium on Motivation: Vol. 38. Perspectives on motivation (pp. 237-288). Lincoln: University of Nebraska Press.

[29] Ryan, R. M. (1982). Control and information in the intrapersonal sphere: An extension of cognitive evaluation theory. Journal of Personality and Social Psychology, 43, 450-461. https://doi.org/10.1037/0022-3514.43.3.450

[30] Kozma R. B. (2008) Comparative Analysis of Policies for ICT in Education. In J. Voogt \& G. Knezek (eds.), International Handbook of Information Technology in Primary and Secondary Education: Springer International Handbook of Information Technology in Primary and Secondary Education (vol 20). Boston, MA: Springer. https://doi.org/10.1007/978-0387-73315-9 68

[31] OECD (2017). OECD Science, Technology and Industry Scoreboard 2017: The digital transformation. Paris: OECD Publishing, http://dx.doi.org/10.1787/9789264268821-en. https://doi.org/10.1787/9789264268821-en

[32] Wagner, D., Day, B., James, T., Kozma, R. B., Miller, J. \& Unwin, T. (2005). Monitoring and evaluation of ICT in education projects. A Handbook for Developing Countries. Washington DC: InfoDev/World Bank.

[33] Condie, R. \& Munro, R. (2007). The impact of ICT in schools: A landscape review. Strathclyde: University of Strathclyde.

[34] Passey, D., Rogers, C., Machell, J., McHugh, G. \& Allaway, D. (2003). The Motivational Effect of ICT on Pupils. London: Department for Education and Skills.

[35] Aguiar, M. V. \& Cuesta, H. (2009). Importancia de trabajar las TIC en Educación Infantil a través de Métodos como las WebQuest. Revista de Medios y Educación, 34: 81-94.

[36] Clares, J., \& Gil, J. (2008). Recursos tecnológicos y metodologías de enseñanza en titulaciones del ámbito de las ciencias de la educación. Bordón, 60(3), 21-33.

[37] Carnoy, M. (2004). Las TIC en la enseñanza: posibilidades y retos. Retrieved from http://www.uoc.edu/inaugural04/dt/esp/carnoy1004.pdf. 
[38] Preston, C., Cox, M. J. \& Cox, K. M. J. (2000). Teachers as Innovators in Learning: What motivates teachers to use ICT. (1st ed.) Croydon: Mirandanet.

[39] Edmunds, R., Thorpe, M. \& Conole, G. (2012). Student attitudes towards and use of ICT in course study, work and social activity: A technology acceptance model approach. British Journal of Educational Technology, 43(1), 71-84. https://doi.org/10.1111/j.1467$\underline{8535.2010 .01142 . \mathrm{x}}$

[40] Méndez, D. (2013) El aprendizaje cooperativo y la enseñanza tradicional en electricidad y magnetismo en secundaria. Enseñanza de las ciencias, No. extra, 2297-2302.

[41] Méndez, D. (2015). Estudio de las motivaciones de los estudiantes de secundaria de Física y Química y la influencia de las metodologías de enseñanza en su interés. Educación XXI, 18 (2), 215-2355, doi: 10.5944/educXX1.14016.

[42] Gokcearslan, S. (2017). Perspectives of students on acceptance of tablets and self-directed learning with technology. Contemporary educational technology, 8 (1), 40-55.

[43] Sharples, M., Taylor, J., \& Vavoula, G. (2005). Towards a theory of mobile learning. In H. van der Merwe \& T. Brown, Mobile technology: The future of learning in your hands, mLearn 2005 Book of Abstracts (p. 58). Cape Town, South Africa: mLearn 2005.

[44] Sharples, M., Taylor, J., \& Vavoula, G. (2007). A Theory of Learning for the Mobile Age. In R. Andrews \& C. Haythornthwaite (eds.), The Sage Handbook of Elearning Research (pp. 221-47). London: Sage. https://doi.org/10.4135/9781848607859.n10

[45] Méndez, D. \& Hargis, J. (2014). The effect of the computers in the learning of formulation with secondary students. Journal of science education, 15 (1), 19-21.

[46] Méndez, D. \& Slisko, J. (2013). Software Socrative and Smartphones as Tools For Implementation of Basic Processes of Active Physics Learning in Classroom: An Initial Feasibility Study With Prospective Teachers. European Journal of Physics Education, 4 (2), 17 24.

[47] Méndez, D. (2012). The experience of learning Physics through the application of ICT. Energy Education Science and Technology Part B. Social and Educational Studies, 4(1), 674-679.

[48] Sanz, J. J. (2013). Ipad y motivación. Revista Caribeña de Ciencias Sociales, 2013, 10.

\section{Authors}

David Mendez has been awarded by his $\mathrm{PhD}$, has been invited as an invited speaker by AAPT, has published papers about Technology and Science Education.

Miriam Mendez is a Mathematics and $\mathrm{PhD}$ in Education. She has published about Mathematics teaching, cooperative learning and the effect of technology in the classroom.

Juana Anguita is $\mathrm{PhD}$ in Education, she trains teachers and has published about the use of technology in the classroom.

Article submitted 14 June 2018. Resubmitted 28 July 2018. Final acceptance 30 July 2018. Final version published as submitted by the uthors. 